\title{
PENGARUH RASIO KEUANGAN TERHADAP NILAI PERUSAHAAN YANG TERGABUNG DALAM INDEKS KOMPAS100
}

\section{G.A. Sri Oktaryani ${ }^{1}$, Awafiq Abdurrazak ${ }^{2}$, Iwan Kusuma Negara ${ }^{3}$}

1,2,3 Faculty of Economics and Business, University of Mataram, Indonesia.

E-mail: oktaryani@gmail.com

wafikwafik65@gmail.com

\begin{tabular}{|c|c|}
\hline & ABSTRACT \\
\hline $\begin{array}{l}\text { Keywords: } \\
\text { Profitability; liquidity; solvability; activity; } \\
\text { firm value } \\
\text { Kata Kunci: } \\
\text { Profitabilitas; likuiditas; solvabilitas; } \\
\text { aktivitas; nilai perusahaan } \\
\text { How to cite: } \\
\text { Oktaryani, G. A. S., Abdurrazak, A., } \\
\text { Negara, I. K., (2021). Pengaruh Rasio } \\
\text { Keuangan Terhadap Nilai Perusahaan Yang }\end{array}$ & $\begin{array}{l}\text { The firm's goal is to maximize the firm value or wealth } \\
\text { for its shareholders. The purpose of this research is to } \\
\text { examine the effects of profitability ratio, liquidity ratio, } \\
\text { solvency ratio, and activity ratio on the firm value } \\
\text { which are part of Kompas-100 index during period } \\
2015 \text { - } 2019 \text {. Sample are selected by using purposive } \\
\text { sampling method. The analysis technique used is } \\
\text { multiple linear regression analysis. This study indicate } \\
\text { that the profitability, liquidity and activity ratio have } \\
\text { positive and significant effect on firm value. } \\
\text { Meanwhile, the solvability has a negative and } \\
\text { significant effect on firm's value. }\end{array}$ \\
\hline $\begin{array}{l}\text { Tergabung Dalam Indeks Kompas100. } \\
\text { JMM UNRAM, 10(3),160-174 } \\
\text { DOI: } \\
\text { https://doi.org/10.29303/jmm.v10i3.66 } \\
\underline{3}\end{array}$ & $\begin{array}{l}\text { Memaksimalkan nilai perusahaan adalah tujuan } \\
\text { dari perusahaan. Tujuan penelitian ini adalah } \\
\text { untuk menguji pengaruh rasio profitabilitas, } \\
\text { likuiditas, solvabilitas dan aktivitas terhadap nilai } \\
\text { perusahaan yang termasuk dalam indeks } \\
\text { Kompas-100 pada tahun } 2015-2019 \text {. Sampel } \\
\text { dalam penelitian ini dipilih dengan metode } \\
\text { purposive sampling. Tehnik analisis yang } \\
\text { digunakan adalah analisis regresi linier berganda. } \\
\text { Hasil penelitian menunjukkan bahwa rasio } \\
\text { profitabilitas, likuiditas dan aktivitas berpengaruh } \\
\text { positif dan signifikan terhadap nilai perusahaan. } \\
\text { Sedangkan rasio solvabilitas berpengaruh negatif } \\
\text { dan signifikan terhadap nilai perusahaan. }\end{array}$ \\
\hline & $\begin{array}{l}\text { Copyright ( 2021. G.A. Sri Oktaryani, Awafiq } \\
\text { Abdurrazak, Iwan Kusuma Negara. All rights } \\
\text { reserved. }\end{array}$ \\
\hline
\end{tabular}




\section{PENDAHULUAN}

Perusahaan adalah organisasi yang dijalankan oleh manajemen perusahaan dan bertujuan untuk memperoleh keuntungan dengan cara menyediakan barang atau jasa. Setiap manajemen perusahaan menginginkan agar perusahaan dapat tetap bertahan dan beroperasi di masa depan oleh karena itu perusahaan dalam mencapai tujuannya harus selalu memiliki strategi yang jelas (Lumentut \& Mangantar, 2019). Memaksimalkan nilai perusahaan adalah tujuan dari perusahaan. Nilai perusahaan ini dapat dicerminkan oleh harga saham perusahaan (Susanti, 2010). Masa sekarang perekonomian global memberikan tantangan yang sangat besar bagi perusahaan salah satunya persaingan yang semakin tinggi antar perusahaan. Hal ini menuntut setiap perusahaan agar selalu mempertahankan keunggulan bisnis yang dimiliki dan juga menuntut perusahaan dalam meningkatkan nilai perusahaan. Nilai perusahaan yang tinggi akan memberikan kesejahteraan bagi para investor.

Nilai perusahaan merupakan pencapaian perusahaan sebagai indikasi dari kepercayaan publik sejak perusahaan berdiri hingga saat ini. Tingginya nilai perusahaan dapat menciptakan kepercayaan pasar terhadap keadaan bisnis perusahaan saat ini dan juga prospek perusahaan di masa yang akan datang (Wijaya \& Sedana, 2015). Persepsi investor terhadap perusahaan dapat dipengaruhi oleh nilai perusahaan yang mencerminkan kinerja perusahaan. Secara harfiah nilai suatu perusahaan bisa diukur dengan nilai pasar dari harga sahamnya. Bagi perusahaan terbuka, maka nilai pasar wajar perusahaan ditentukan oleh mekanisme permintaan dan penawaran pasar, yang dapat dilihat dalam listing price. Untuk perusahaan yang tidak tercatat, nilai pasar wajar ditentukan oleh perusahaan jasa penilai (Haryadi, 2016). Pengukuran nilai perusahaan dilakukan dengan menggunakan Tobin's $Q$ karena dianggap sebagai yang terbaik (Wahyuni et al., 2018). Tobin's $Q$ tidak hanya mencakup modal perusahaan, tetapi semua asset, serta kewajiban serta modal perusahaan. Tujuan suatu perusahaan adalah untuk memaksimalkan nilai perusahaan atau kekayaan para pemegang sahamnya (Fitri, 2013). Semakin tinggi harga saham, semakin tinggi tingkat pengembalian investor. Hal ini berdampak pada semakin tingginya nilai perusahaan itu sendiri terkait dengan tujuan dari perusahaan. Untuk mencapai optimalisasi dari nilai perusahaan dapat melalui penerapan dan pelaksanaan fungsi manajemen keuangan. Menurut Salama et al., (2019) suatu keputusan keuangan yang dibuat dapat mempengaruhi keputusan keuangan lainnya dan mempengaruhi nilai perusahaan.

Indeks kompas100 adalah indeks saham yang beranggotakan 100 saham perusahaan terbuka yang terdaftar di BEI. Perusahaan yang tergabung dalam indeks kompas100 diperkirakan mewakili sekitar 70\% hingga 80\% dari kapitalisasi pasar sebesar Rp 1.582 triliun dari seluruh saham yang tercatat di BEI. Hal ini membuat investor dapat mengkonfirmasi kecenerungan dari pergerakan indeks dengan mengamati pergerakan indeks kompas100. Pada awal tahun 2019 telah terjadi peningkatan kinerja perusahaan yang tergabung pada indeks kompas100 mengalahkan kinerja IHSG dan indeks lainnya, dimana indeks kompas100 menguat secara year to date yaitu mencapai 4,41\% mengalahkan IHSG yang naik sebesar 4,31\%. Indeks kompas100 juga menorehkan performa dibandingkan indeks lainnya seperti LQ45 yang mencatat kenaikan sebesar 3,26\%, lalu IDX30 yang menguat pada angka 3,14\%, dan IDX80 pada angka 2,90\%. Hal ini memberi sinyal kepada investor bahwa perusahaan yang tergabung dalam indeks kompas100 memiliki fundamental yang baik untuk dijadikan pilihan investasi. Kinerja perusahaan yang tergabung dalam indeks kompas100 sejak tahun 2015 hingga 2019 apabila dilihat dari 
persentase kenaikan harga sahamnya cenderung lebih tinggi dari IHSG yang merupakan indeks dari seluruh perusahaan yang terdaftar di BEI. Berikut disajikan grafik mengenai pergerakan persentase kenaikan harga saham dan harga saham terakhir dari indeks kompas100 dan IHSG selama periode 2015-2019.

Grafik 1.1 Persentase Kinerja

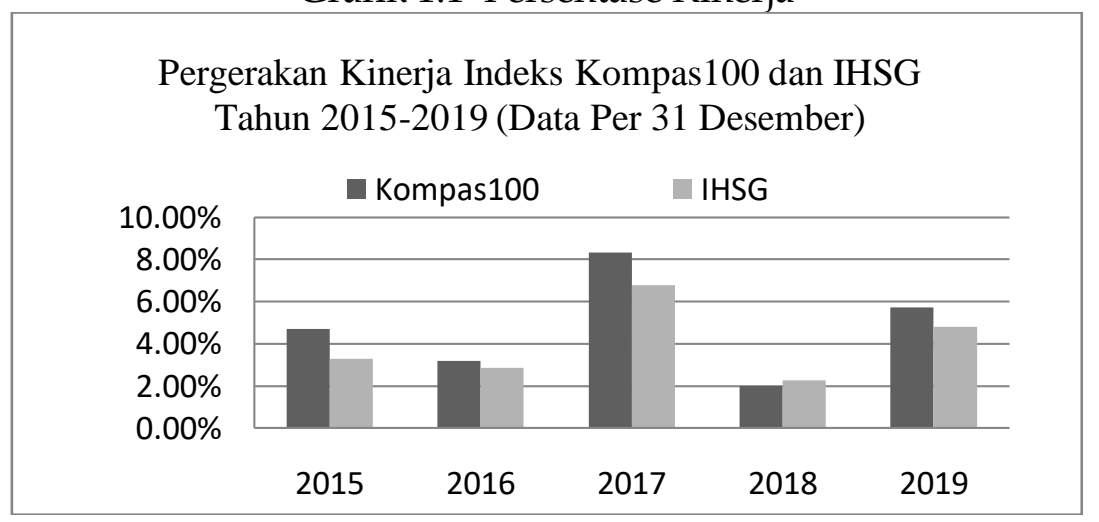

Grafik 1.1 menunjukkan bahwa kinerja dari indeks kompas100 relatif lebih tinggi dibandingkan dengan kinerja IHSG kecuali pada tahun 2018 kompas100 mengalami penurunan kinerja menjadi 2,00\% lebih rendah dari IHSG yang juga menurun pada 2,28\% .

Pengukuran dengan cara analisis dan evaluasi laporan keuangan perusahaan dapat dilakukan untuk mengetahui nilai suatu perusahaan. Analisis yang dilakukan yaitu dengan menganalisis rasio keuangan perusahaan seperti rasio profitabilitas, likuiditas, solvabilitas, dan aktivitas (Johnson, 2015). Dalam rasio profitablitas, terdapat proksi Return on Equity (ROE) yang digunakan untuk mengukur kemampuan modal dalam menghasilkan profit bagi para investor (Sujarweni, 2019). ROE merupakan indikator penting bagi investor dalam mengetahui sejauh mana efektivitas dan efisiensi dari penggunaan modal oleh manajemen perusahaan. Nilai ROE yang tinggi menandakan perusahaan memiliki kemampuan menghasilkan profit yang tinggi bagi investor. Penelitian oleh Novalia et al. (2015), dan juga Triagustina et al. (2014) menyimpulkan ROE berpengaruh positif terhadap nilai perusahaan. Penelitian lain oleh Amijaya et al. (2015), menunjukkan ROE berpengaruh negatif terhadap nilai perusahaan. Rasio likuiditas diproksikan dengan Current Ratio (CR) merupakan perbandingan antara aktiva lancar dengan hutang lancar Hasania et al. (2016). Tinggi rendahnya CR mempengaruhi minat investor untuk berinvestasi ke perusahaan (Kahfi et al., 2018). Semakin besar nilai CR semakin tinggi kemampuan perusahaan dalam memenuhi kewajiban jangka pendeknya. Penelitian Amijaya et al. (2015) meyimpulkan CR berpengaruh positif pada nilai perusahaan. Penelitian lain dilakukan oleh Kushartono \& Nurhasanah (2018), dan Sianipar et al. (2018) masing-masing menyimpulkan CR berpengaruh negatif terhadap nilai perusahaan.

Rasio solvabilitas dapat diukur menggunakan Debt to Equity Ratio (DER) yang merupakan rasio untuk mengetahui perbandingan antara hutang dan ekuitas perusahaan (Kahfi et al., 2018). Tingginya nilai DER suatu perusahaan dapat menimbulkan risiko kerugian yang tinggi. Tingkat risiko yang tinggi akan membuat investor menawar harga saham perusahaan semakin rendah. Penelitian oleh Dwi (2017), dan Novalia et al. (2015), masing- masing menyimpulkan bahwa DER berpengaruh positif dan negatif terhadap nilai perusahaan. Hasil berbeda diperoleh pada penelitian Haryati \& Ayem (2016) yang menyatakan DER tidak berpengaruh terdahap nilai perusahaan. Selanjutnya rasio aktivitas diproksikan dengan Total Assets Turnover (TATO) merupakan rasio yang menggambarkan 
efektivitas penggunaan aktiva perusahaan dalam menghasilkan laba Kasmir, (2014). nilai TATO yang tinggi menunjukkan tingkat perolehan laba juga tinggi sehingga berdampak pada nilai perusahaan. penelitian Sianipar et al. (2018), menyimpulkan TATO berpengaruh positif pada nilai perusahaan. Penelitian lain oleh Dwi (2017) yang menyimpulkan bahwa TATO tidak berpengaruh terhadap nilai perusahaan. Berdasarkan latar belakang dan hasil penelitian-penelitian sebelumnya ditemukan adanya perbedaan hasil sehingga dapat dikatakan adanya hasil penelitian yang tidak konsisten. Berdasarkan hal tersebut peneliti ingin meneliti lebih lanjut mengenai pengaruh dari rasio profitabilitas (ROE), likuiditas (CR), solvabilitas (DER), dan aktivitas (TATO) terhadap nilai perusahaan.

\section{KAJIAN PUSTAKA}

\subsection{Landasan Teori}

\subsubsection{Teori Struktur Modal}

Struktur modal digambarkan sebagai bentuk dari proporsi keuangan perusahaan yaitu antara modal perusahaan yang diakibatkan oleh long term debt dan modal sendiri sebagai sumber pembiayaan perusahaan (Fahmi, 2016). Manajer keuangan perusahaan menentukan struktur modal sebagai salah satu faktor fundamental yang menunjang kegiatan perusahaan. Dalam teori struktur modal, tujuan dari teori tersebut adalah sebagai landasan teoritis untuk mengetahui struktur modal yang optimal. Pengoptimalan struktur modal dapat dicapai jika terdapat beberapa risiko yang terlibat dan dapat memberikan nilai maksimal bagi perusahaan. Dalam teori struktur modal diketahui Trade off theory dimana perusahaan akan berhutang sampai pada titik tertentu, dimana penghematan pajak (tax shields) dari tambahan hutang sama dengan biaya kesulitan keuangan (financial distress) (Sri et al. (2013). Biaya kesulitan keuangan (financial distress) seperti biaya kebangkrutan (bankruptcy costs), dan biaya agensi (agency costs) meningkat diakibatkan oleh kredibilitas perusahaan yang menurun. Teori Trade off dalam menentukan struktur modal yang optimal memasukkan dan mencakup beberapa faktor seperti pajak, biaya agensi (agency costs) dan biaya kesulitan keuangan (financial distress) tetapi tetap mempertahankan asumsi efisiensi pasar sebagai imbangan dan manfaat penggunaan hutang.

\subsubsection{Teori Keagenan}

Teori keagenan (Agency Theory) merupakan suatu hubungan dimana para manajer yang berperan sebagai agen yang dipercayakan oleh pemegang saham dalam hal ini adalah prinsipal untuk menjalankan perusahaan. Secara khusus, teori keagenan pertama kali diusulkan oleh Jensen \& Meckling. Menurutnya, manajer suatu perusahaan adalah "agen" dan pemegang saham sebagai "prinsipal". Hubungan antara agen dan prinsipal menciptakan perbedaan kepentingan di dalam perusahaan. Hal ini ditunjukkan oleh masing-masing pihak yang berusaha untuk mencapai kesejahteraan yang dicita-citakan.

\subsubsection{Teori Sinyal}

Teori Sinyal (Signalling Theory) menjelaskan bagaimana sinyal-sinyal keberhasilan dan kegagalan dari manajemen perusahaan atau agen dapat mempengaruhi keputusan prinsipal selaku pemilik perusahaan. Menurut Dwi (2017) teori sinyal adalah teori yang berhubungan dengan naik turunnya harga pasar, yang dapat mempengaruhi keputusan investor. Sinyal ini ditampilkan sebagai informasi tentang apa yang telah dilakukan oleh manajemen (agen) untuk merealisasikan keinginan pemilik (prinsipal). Brigham \& Houston dalam Moniaga (2013) menunjukkan bahwa signal adalah petunjuk bagi investor yang dilakukan oleh manajemen mengenai cara manajemen perusahaan dalam melihat prospek perusahaan di masa depan. Sinyal yang diberikan oleh manajemen kepada investor tersebut merupakan upaya untuk mengurangi asimetri informasi. 


\subsubsection{Nilai Perusahaan}

Nilai perusahaan merupakan pencapaian perusahaan sejak perusahaan berdiri hingga saat ini. Pengertian lain yaitu oleh Anzlina \& Rustam (2013), nilai perusahaan mencerminkan harga pasar sahamnya dan jumlah saham yang dikeluarkan oleh perusahaan. Dengan pelaksanaan fungsi manajemen keuangan, maka pengoptimalan dari nilai perusahaan dapat dicapai. Menurut Salama et al, (2019) satu keputusan keuangan yang dibuat dapat berpengaruh pada keputusan keuangan lainnya sehingga mempengaruhi nilai perusahaan. Pengukuran nilai perusahaan dilakukan menggunakan Tobin's $Q$ karena dianggap sebagai yang terbaik (Wahyuni et al., 2018). Tobin's $Q$ mencakup semua hutang dan juga ekuitas dari perusahaan, ini mencakup juga semua asset perusahaan bukan hanya ekuitas perusahaan. Hasil pengukuran menggunakan metode Tobins' $Q$ memperlihatkan aspek fundamental dari perusahaan, sentimen pasar, serta bagaimana pandangan investor dalam menilai suatu perusahaan. karena dalam Rumus dari Tobin's $Q$ adalah sebagai berikut :

$$
\text { Tobin's } Q=\frac{\text { MVE }+ \text { Debt }}{\text { Total Aktiva }}
$$

MVE (Market Value of Equity) merupakan nilai kapitalisasi pasar perusahaan. Kapitalisasi pasar dapat diketahui dengan menghitung jumlah saham beredar pada akhir tahun dikali (closing price). Debt merupakan nilai total kewajiban perusahaan lalu dibagi dengan total aktiva perusahaan pada periode laporan keuangan. Pengukuran menggunakan analisis dan evaluasi laporan keuangan perusahaan dapat dilakukan untuk mengetahui nilai suatu perusahaan. Analisis yang dilakukan melalui analisis rasio keuangan perusahaan seperti rasio profitabilitas, likuiditas, solvabilitas, dan aktivitas (Johnson, 2015).

\subsubsection{Rasio Profitabilitas}

Rasio profitabilitas digunakan untuk mengukur dan menilai kemampuan perusahaan dalam mencari keuntungan sehingga dapat dilihat apakah perusahaan dapat memberikan keuntungan atau tidak (Kasmir, 2014). Dalam pengukuran rasio profitabilitas, dapat menggunakan Return on Equity (ROE) yang mengukur kemampuan dari ekuitas dalam menghasilkan imbal hasil atau keuntungan bagi para pemegang saham (Sujarweni, 2019). ROE merupakan indikator penting bagi investor dalam mengetahui sejauh mana efektivitas dan efisiensi dari penggunaan ekuitas oleh manajemen perusahaan. Rumus dari ROE adalah sebagai berikut:

$$
\mathrm{ROE}=\frac{\mathrm{EAT}}{\text { Total Ekuitas }}
$$

\subsubsection{Rasio Likuiditas}

Rasio likuiditas berguna dalam memberikan gambaran tentang kesanggupan dari perusahaan untuk memenuhi kewajiban-kewajiban jangka pendeknya (Permana \& Rahyuda, 2018). Rasio Likuiditas menunjukkan seberapa besar aset lancar perusahaan serta seberapa likuid perusahaan dalam mencapai kinerja keuangannya seperti pada kewajiban jangka pendek. Current Ratio (CR) adalah rasio yang paling umum digunakan untuk mengukur likuiditas suatu perusahaan. Pengukuran menggunakan Current Ratio mampu menunjukkan kemampuan perusahaan untuk membayar kewajiban jangka pendek sekaligus dapat menunjukkan margin of safety bagi kreditur yang memberi pinjaman pada perusahaan. Rumus dari Current Ratio adalah sebagai berikut :

$$
\text { Current Ratio }=\frac{\text { Aktiva Lancar }}{\text { Hutang Lancar }}
$$




\subsubsection{Rasio Solvabilitas}

Rasio Solvabilitas dalam rasio keuangan berfungsi dalam mengukur kemampuan perusahaan untuk memenuhi kewajiban jangka pendek dan jangka panjangnya (Sujarweni, 2019). Debt to Equity Ratio (DER) adalah perbandingan antara hutang dan ekuitas dalam membiayai kegiatan perusahaan. DER membantu investor dalam menilai perbandingan antara jumlah dana yang disediakan oleh kreditur dengan jumlah dana yang dipegang perusahaan (Kahfi et al., 2018). Rumus dari Debt to Equity Ratio adalah sebagai berikut:

$$
D E R=\frac{\text { Total Hutang }}{\text { Total Ekuitas }}
$$

\subsubsection{Rasio Aktivitas}

Rasio aktivitas menurut Kasmir, (2014) mampu mengukur tingkat efisiensi penggunaan sumber daya perusahaan. Efisiensi dapat dicapai, seperti pada bagian pemasaran atau penjualan, penagihan piutang, dan ketepatan pada bagian lainnya. Rasio aktivitas mampu memperhitungkan kemampuan perusahaan dalam menjalankan kegiatan operasional perusahaan sehari-hari. Total Assets Turnover (TATO) merupakan rasio yang melihat sejauh mana tingkat perputaran dana dalam total asset selama periode waktu tertentu atau kemampuan dari modal untuk memperoleh keuntungan Rumus dari Total Assets Turnover adalah sebagai berikut :

$$
\text { TATO }=\frac{\text { Sales }}{\text { Total Aktiva }}
$$

\subsection{Rerangka Konseptual}

Berdasarkan penjelasan dari latar belakang, dan tinjauan pustaka di atas, rerangka konseptual penelitian ini adalah sebagai berikut :

\section{Gambar 2.1 Rerangka Konseptual}

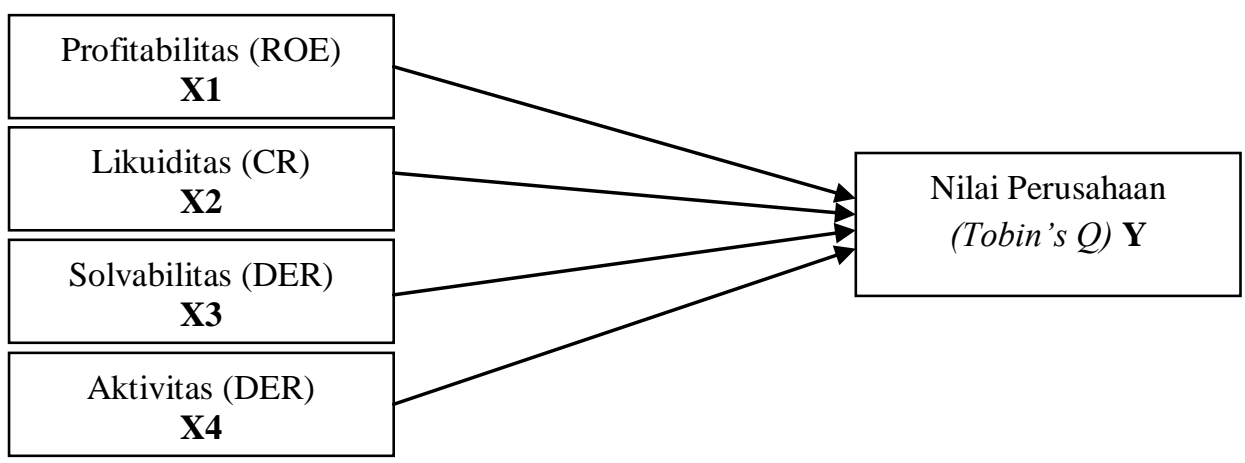

\subsection{Pengembangan Hipotesis}

\subsubsection{Pengaruh Rasio Profitabilitas terhadap Nilai Perusahaan}

Rasio profitabilitas digunakan untuk mengukur dan menilai kemampuan perusahaan dalam mencari keuntungan. Dari rasio profitabilitas dapat dilihat tingkat profitabilitas perusahaan. Pengukuran rasio profitabilitas, dapat menggunakan Return on Equity (ROE) yang mengukur kemampuan ekuitas dalam menghasilkan return bagi para pemegang saham. Perusahaan dengan ROE yang tinggi, menunjukkan kemampuannya dalam menghasilkan return tinggi bagi investor. Sesuai dengan teori sinyal hal ini akan memberi daya tarik kepada investor untuk berinvestasi di perusahaan karena pada umumnya investor sangat bergantung pada sinyal fundamental perusahaan. Penelitian dilakukan oleh Novalia et al. (2015), dan Triagustina et al. (2014) menunjukkan bahwa ROE 
berpengaruh positif terhadap nilai perusahaan. Penelitian lain oleh Rachmawati \& Pinem (2015), dan Lumoly et al. (2018) menyatakan bahwa ROE berpengaruh positif terhadap nilai perusahaan. Atas dasar ini, dinyatakan hipotesis sebagai berikut :

H1 : Rasio Profitabilitas berpengaruh positif terhadap nilai perusahaan indeks kompas100 yang terdaftar di BEI periode 2015-2019.

\subsubsection{Pengaruh Rasio Likuiditas terhadap Nilai Perusahaan}

Rasio likuiditas digunakan untuk mengetahui kemampuan perusahaan dalam memenuhi kewajiban jangka pendeknya. Perusahaan dikatakan sehat jika tingkat likuiditas perusahaan tinggi sehingga mempengaruhi nilai perusahaan. Atas dasar ini, manajemen sebagai agen perusahaan dituntut untuk dapat mengembalikan investasi yang telah ditanam investor pada perusahaan karena investor memiliki urgensi dalam pengembalian atas investasinya. Rasio likuiditas dapat dihitung dengan Current Ratio (CR) dengan cara membandingkan aktiva lancar dengan hutang lancar. Semakin tinggi kemampuan perusahaan dalam memenuhi kewajiban jangka pendeknya maka semakin besar nilai dari Current Ratio. Penelitian dilakukan oleh Kahfi et al. (2018), dan Amijaya et al. (2015), menemukan bahwa CR memiliki pengaruh positif pada nilai perusahaan. Anzlina \& Rustam (2013) menemukan bahwa CR berpengaruh negatif terhadap nilai perusahaan. Atas dasar tersebut, maka dinyatakan hipotesis sebagai berikut :

H2 : Rasio Likuiditas berpengaruh positif terhadap nilai perusahaan indeks kompas100 yang terdaftar di BEI periode 2015-2019.

\subsubsection{Pengaruh Rasio Solvabilitas terhadap Nilai Perusahaan}

Rasio solvabilitas adalah rasio yang digunakan untuk mengukur kemampuan perusahaan dalam memenuhi kewajiban jangka pendek dan jangka panjangnya. Rasio solvabilitas menunjukkan bagaimana perusahaan mengelola hutangnya dalam rangka memperoleh keuntungan. Rasio solvabilitas dapat dihitung menggunakan Debt to Equity Ratio (DER). Nilai DER tinggi, menunjukkan perusahaan berisiko tinggi karena tingkat hutang perusahaan terhadap ekuitas perusahaan tinggi. Berdasarkan Trade off theory dimana perusahaan akan berhutang menggunakan dana eksternal sampai pada titik tertentu yaitu titik optimal. Apabila perusahaan berhutang terlalu banyak dan melewati titik optimal, perusahaan akan menanggung beban bunga yang terlalu tinggi. Beban bunga yang tinggi tersebut dapat memberikan risiko kebangkrutan yang tinggi pada perusahaan akibat dari tingginya tingkat hutang perusahaan. Hal tersebut dapat menjadi sinyal negatif bagi investor yang berdampak pada turunnya nilai perusahaan yang tercermin pada harga sahamnya. Jika risiko perusahaan tinggi atau nilai DER tinggi, investor akan menetapkan harga rendah pada saham perusahaan. Sebaliknya jika nilai DER rendah, investor akan memberi harga yang tinggi pada saham perusahaan. Penelitian oleh Amijaya et al. (2015) menemukan bahwa DER berpengaruh positif. Pada penelitian lain yakni Novalia et al. (2015), dan Permana \& Rahyuda (2018), menemukan bahwa DER berpengaruh negatif terhadap nilai perusahaan. Atas dasar tersebut, maka dinyatakan hipotesis sebagai berikut : H3 : Semakin tinggi rasio solvabilitas akan berpengaruh pada semakin rendah nilai perusahaan indeks kompas100 yang terdaftar di BEI periode 2015-2019.

\subsubsection{Pengaruh Rasio Aktivitas terhadap Nilai Perusahaan}

Rasio aktivitas mengukur tingkat efektivitas perusahaan dalam mengelola aktivanya. Rasio aktivitas digunakan untuk mengetahui penggunaan aktiva perusahaan dibandingkan dengan penjualan selama periode tertentu. Rasio aktivitas dibuat agar prinsipal dapat melihat apakah jumlah aktiva pada setiap jenis laporan keuangan termasuk dalam kategori tinggi, wajar, atau rendah. Rasio aktivitas dihitung dengan Total Assets Turnover (TATO). Perusahaan dengan nilai TATO yang besar menunjukkan kemampuan perusahaan dalam meningkatkan penjualan perusahaan sehingga tingkat perolehan laba 
juga semakin besar. Sesuai dengan teori sinyal yang menjelaskan bagaimana sinyal-sinyal keberhasilan dan kegagalan perusahaan bisa mempengaruhi keputusan pemilik perusahaan, sehingga nilai TATO yang besar dapat memberikan sinyal positif kepada investor tentang kinerja perusahaan yang baik. Penelitian oleh Lumentut \& Mangantar (2019), dan Sianipar et al. (2018) menemukan bahwaTATO berpengaruh positif terhadap nilai perusahaan. Penelitian lain yakni pada penelitian Rinnaya et al. (2016) TATO juga berpengaruh positif terhadap nilai perusahaan. Atas dasar tersebut, dinyatakan hipotesis sebagai berikut :

H4 : Rasio Aktivitas berpengaruh positif terhadap nilai perusahaan indeks kompas100 yang terdaftar di BEI periode 2015-2019.

\section{METODE PENELITIAN}

Penelitian ini meneliti perusahaan yang tergabung dalam indeks kompas100 dan terdaftar di Bursa Efek Indonesia dengan mengambil data yang diperlukan melalui website resmi di www.idx.co.id. Dalam memilih sampel, digunakan metode purposive sampling dengan kriteria pengambilan sampel sebagai berikut:

1. Perusahaan yang terdaftar di indeks kompas100 dan masih terdaftar periode 2015-2019

2. Perusahaan menerbitkan laporan keuangan dan data yang dibutuhkan periode 20152019

3. Bukan termasuk sektor perbankan

4. Perusahaan memiliki nilai DER di bawah $100 \%$

Berdasarkan kriteria tersebut, telah diperoleh 18 perusahaan yang tergabung dalam indeks kompas100 sebagai sampel pada penelitian. Dalam penelitian ini, data yang digunakan dan diolah merupakan data sekunder Sedangkan metode pengumpulan data dalam penelitian ini menggunakan studi kepustakaan, dan juga dokumentasi.

Dalam menganalisis data, penelitian ini analisis regresi linier berganda untuk meneliti pengaruh variabel independen yang lebih dari satu terhadap satu variabel dependen. Dilakukan juga uji asumsi klasik yakni uji normalitas menggunakan Kolmogorov-smirnov, uji multikolinieritas, uji heteroskedastisitas dengan uji glejser, dan uji autokorelasi menggunakan uji run test. Dalam menguji kelayakan dari model regresi, dilakukan uji goodness of fit dan uji koefisien determinasi $\left(\mathrm{R}^{2}\right)$ serta uji hipotesis dengan menggunakan uji t.

\section{HASIL DAN PEMBAHASAN}

\subsection{Hasil}

\subsubsection{Uji Asumsi Klasik}

\section{Uji Normalitas}

Tujuan dari uji normalitas adalah untuk memverifikasi variabel-variabel dalam model regresi apakah berdistribusi normal atau tidak. apabila variabel penelitian berdistribusi normal atau mendekati normal maka model regresi dikatakan baik. Uji normalitas data menggunakan statistik dapat dilakukan dengan uji kolmogorov-Smirnov sebagai berikut : 
Tabel 4.2 Uji Kolmogorov-Smirnov

\begin{tabular}{|ll|r|}
\hline \multicolumn{2}{|c|}{ One-Sample Kolmogorov-Smirnov Test } \\
\hline $\mathrm{N}$ & $\begin{array}{c}\text { Unstandardized } \\
\text { Residual }\end{array}$ \\
Normal Parameters ${ }^{\mathrm{a}, \mathrm{b}}$ & Mean & 90 \\
& Std. Deviation & .0000000 \\
Most Extreme Differences & Absolute & .72671928 \\
& Positive & .058 \\
& Negative & -.058 \\
Test Statistic & & .058 \\
Asymp. Sig. (2-tailed) & & $.200^{\mathrm{c}, \mathrm{d}}$ \\
\hline
\end{tabular}

Sumber : data sekunder yang diolah

Berdasarkan hasil uji normalitas pada Tabel 4.2, menunjukkan bahwa data berdistribusi normal. Hal ini dibuktikan dengan pengujian pada nilai Asymp.sig (2-tailed) sebesar 0,200 yang nilainya berada di atas taraf signifikansi yaitu 0,05 .

\section{Uji Multikolinieritas}

Uji Multiltikolinieritas digunakan untuk menentukan apakah terdapat gejala multikolinieritas pada model regresi dengan cara memeriksa seberapa besar inter kolerasi antar variabel independen. Adanya multikolinieritas dapat dikonfirmasi dengan nilai Tolerance dan nilai Variance Inflation Factor (VIF). Hasil dari uji multikolinieritas ditunjukkan pada tabel berikut ini :

Tabel 4.3 Uji Multikolinieritas

\begin{tabular}{|l|l|l|l|}
\hline \multicolumn{1}{|c|}{ Variabel } & Tolerance & VIF & Keterangan \\
\hline $\begin{array}{l}\text { Rasio Profitabilitas } \\
\text { (ROE) }\end{array}$ & 0,725 & 1,380 & Tidak terjadi multikolinieritas \\
\hline Rasio Likuiditas (CR) & 0,666 & 1,502 & Tidak terjadi multikolinieritas \\
\hline Rasio Solvabilitas (DER) & 0,667 & 1,500 & Tidak terjadi multikolinieritas \\
\hline Rasio Aktivitas (TATO) & 0,729 & 1,373 & Tidak terjadi multikolinieritas \\
\hline
\end{tabular}

Sumber : data sekunder yang diolah

Tabel 4.3, menunjukkan keempat variabel independen memiliki nilai Tolerance $\geq 0,10$ dan nilai Variance Inflation Factor (VIF) $\leq 10,00$ hal ini sesuai dengan indikator pada uji multikolinieritas. Kesimpulan yang diambil adalah semua variabel independen dalam penelitian ini tidak menunjukkan gejala multikolinieritas.

\section{Uji Heteroskedastisitas}

Tujuan dari uji heteroskedastisitas adalah untuk memeriksa model regresi, apakah terdapat varian yang tidak seragam dari residual pengamatan yang satu ke pengamatan yang lainnya, yang dapat menimbulkan gejala heteroskedastisitas pada model regresi. Dalam penelitian ini gejala heteroskedastisitas diuji dengan melakukan uji glejser. Hasil uji glejser adalah sebagai berikut : 
Tabel 4.4 Uji Glejser

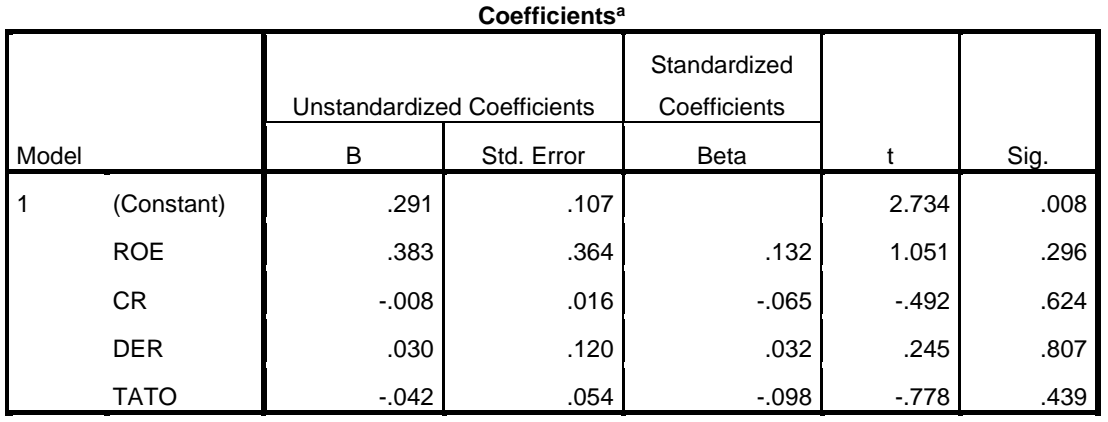

Sumber : data sekunder yang diolah

Berdasarkan tabel di atas nilai signifikan masing-masing variabel nilai signifikansi lebih besar dari 0,05 sehingga dapat ditarik kesimpulan bahwa data tidak menunjukkkan gejala heteroskedastisitas.

\section{Uji Autokorelasi}

Uji Autokorelasi digunakan dalam model regresi linier berganda untuk memeriksa apakah terdapat korelasi antara sisa periode $t$ dengan sisa periode $t-1$ (periode sebelumnya). Uji autokorelasi dalam penelitian ini menggunakan Uji Run Test dengan hasil uji sebagai berikut :

\section{Tabel 4.5 Uji Run Test}

\begin{tabular}{|l|r|}
\hline \multicolumn{2}{|c|}{ Runs Test } \\
\hline & $\begin{array}{c}\text { Unstandardized } \\
\text { Residual }\end{array}$ \\
\hline Test Value $^{\mathrm{a}}$ & -.02509 \\
Cases < Test Value & 45 \\
Cases >= Test Value & 45 \\
Total Cases & 90 \\
Number of Runs & 46 \\
Z & .000 \\
Asymp. Sig. (2-tailed) & 1.000 \\
\hline
\end{tabular}

Sumber : data sekunder diolah

Berdasarkan tabel 4.5, diketahui nilai Asymp sig (2-tailed) adalah 1,000. Dikarenakan nilai tersebut lebih besar daripada nilai 0,05 (Asymp sig (2-tailed) > 0,05), hal ini sesuai dengan indikator uji autokorelasi yang menunjukkan tidak terdapat autokorelasi. Sehingga dapat disimpulkan bahwa dalam model regresi tidak terdapat gejala autokorelasi.

\subsubsection{Uji Kelayakan Model}

\section{Uji F (Goodness of Fit)}

Uji Goodness of Fit digunakan untuk memeriksa serta menguji kelayakan model yang digunakan dalam penelitian. Uji F yang signifikan, menandakan bahwa model regresi layak untuk diteliti. Model Goodness of Fit dapat dilihat dari nilai Uji F tabel analisis of variance (ANOVA), (Ghozali, 2016). Berikut disajikan pada tabel :

Tabel 4.6 Uji F (Goodness of Fit)

\begin{tabular}{|c|c|c|c|c|c|c|}
\hline \multicolumn{7}{|c|}{ ANOVA $^{a}$} \\
\hline & & Sum of Squares & $\mathrm{df}$ & Mean Square & $\mathrm{F}$ & Sig. \\
\hline \multirow[t]{3}{*}{1} & Regression & 96.306 & 4 & 24.077 & 43.540 & $.000^{\mathrm{b}}$ \\
\hline & Residual & 47.003 & 85 & .553 & & \\
\hline & Total & 143.309 & 89 & & & \\
\hline
\end{tabular}

Sumber : data sekunder yang diolah 
Hasil Uji F pada Tabel 4.6 yang telah dihitung menggunakan program SPSS dapat diketahui p-value 0,000, nilai tersebut lebih kecil dari 0,05, maka model regresi dalam penelitian ini dianggap layak untuk diteliti.

\section{Koefisien Determinasi}

Koefisien determinasi $\left(\mathrm{R}^{2}\right)$ digunakan untuk mengukur tingkat kemampuan model dalam menjelaskan perubahan variabel dependen. Nilai dari koefisien determinasi dapat dilihat pada tabel Model Summary sebagai berikut :

Tabel 4.7 Koefisien Determinasi

\begin{tabular}{|l|r|r|r|r|r|}
\hline & & & \multicolumn{1}{|c|}{ Model Summary } \\
Model & $\mathrm{R}$ & R Square & \multicolumn{1}{c|}{$\begin{array}{c}\text { Square } \\
\text { Squared }\end{array}$} & $\begin{array}{c}\text { Std. Error of the } \\
\text { Estimate }\end{array}$ & Durbin-Watson \\
\hline 1 & $.820^{\mathrm{a}}$ & .672 & .657 & .743622 & 2.339 \\
\hline
\end{tabular}

Berdasarkan tabel, diketahui nilai koefisien determinasi $\left(R^{2}\right)$ sebesar 0,672 sehingga dapat disimpulkan pengaruh variabel independen $(X)$ terhadap variabel dependen $(Y)$ sebesar $67,2 \%$ hal ini menunjukkan semakin kuat pengaruh variabel bebas terhadap variabel terikat karena nilai $\mathrm{R}^{2}$.

\subsubsection{Uji Hipotesis}

\section{Uji T}

Uji T menguji masing-masing variabel independen apakah terdapat pengaruh terhadap variabel dependen. Hasil Uji T dapat dilihat pada tabel sebagai berikut :

Tabel 4.8 Analisis Regresi Linier Berganda

\begin{tabular}{|c|c|c|c|c|c|c|}
\hline \multicolumn{7}{|c|}{ Coefficients $^{a}$} \\
\hline \multirow{2}{*}{\multicolumn{2}{|c|}{ Model }} & \multicolumn{2}{|c|}{ Unstandardized Coefficients } & \multirow{2}{*}{$\begin{array}{c}\text { Standardized } \\
\text { Coefficients } \\
\text { Beta }\end{array}$} & \multirow[b]{2}{*}{$\mathrm{t}$} & \multirow[b]{2}{*}{ Sig. } \\
\hline & & $\mathrm{B}$ & Std. Error & & & \\
\hline \multirow[t]{5}{*}{1} & (Constant) & .644 & .372 & & 1.730 & .087 \\
\hline & ROE & 5.692 & 1.272 & .326 & 4.474 & .000 \\
\hline & $\mathrm{CR}$ & .116 & .054 & .163 & 2.138 & .035 \\
\hline & DER & -1.363 & .421 & -.246 & -3.239 & .002 \\
\hline & TATO & 1.246 & .190 & .478 & 6.569 & .000 \\
\hline
\end{tabular}

Sumber : data sekunder yang diolah

Berdasarkan tabel 4.8, dapat disimpulkan sebagai berikut :

1. ROE (X1) memiliki koefisien positif dengan tingkat signifikansi $0,000<0,05$, maka disimpulkan H1 diterima dan Ho ditolak artinya (X1) berpengaruh positif dan signifikan terhadap Nilai Perusahaan (Y).

2. CR (X2) memiliki koefisien positif dengan tingkat signifikansi 0,035<0,05, maka disimpulkan H2 diterima dan Ho ditolak artinya (X2) berpengaruh positif signifikan terhadap Nilai Perusahaan $(Y)$.

3. DER (X3) memiliki koefisien negatif dengan tingkat signifikansi 0,002 <0,05, maka disimpulkan H3 diterima dan Ho ditolak artinya (X3) berpengaruh negatif dan signifikan terhadap Nilai Perusahaan $(Y)$.

4. TATO (X4) memiliki koefisien positif dengan tingkat signifikansi $0,000<0,05$, maka disimpulkan $\mathrm{H} 4$ diterima dan Ho ditolak artinya (X4) berpengaruh positif dan signifikan pada Nilai Perusahaan (Y). 


\subsection{Pembahasan}

1. ROE (X1) berpengaruh positif dan signifikan terhadap Nilai Perusahaan $(Y)$ yang diproksikan dengan Tobin's $Q$ dimana pada saat ROE meningkat, akan berpengaruh pada meningkatnya Nilai Perusahaan. Nilai ROE merepresentasikan kemampuan perusahaan dalam menghasilkan return bagi pemegang saham sehingga semakin tinggi ROE maka semakin baik. Berdasarkan teori sinyal, peningkatan ROE akan memberi daya tarik pada investor untuk berinvestasi pada perusahaan dengan asumsi bahwa investor mengambil keputusan berdasarkan sinyal fundamental perusahaan. Hasil dari penelitian ini selaras dengan penelitian yang dilakukan oleh Bhekti Fitri (2013), Triagustina et al. (2014), Novalia et al. (2015), Rachmawati \& Pinem, (2015), Lubis et al. (2017), dan Lumoly et al. (2018).

2. CR (X2) berpengaruh positif dan signifikan terhadap Nilai Perusahaan (Y) yang diproksikan dengan Tobin's $Q$ dimana pada saat CR meningkat, akan berpengaruh pada meningkatnya nilai perusahaan untuk itu berdasarkan teori keagenan, manajemen perusahaan dituntut agar memberikan return yang memuaskan bagi investor karena investor memiliki urgensi dalam pengembalian atas investasi yang ditanamkan pada perusahaan. Perusahaan dikatakan baik jika tingkat likuiditasnya tinggi karena tingkat likuiditas tinggi memberi sinyal terhadap kemampuan perusahaan dalam memenuhi kewajiban jangka pendeknya. Hasil dari penelitian ini selaras dengan penelitian yang dilakukan oleh Jantana, (2012), Anzlina \& Rustam (2013), Amijaya et al. (2015), dan Kahfi et al. (2018).

3. DER (X3) berpengaruh negatif dan signifikan terhadap Nilai Perusahaan (Y) yang diproksikan dengan Tobin's $Q$ dimana pada saat DER menurun, akan berpengaruh pada meningkatnya Nilai Perusahaan. Nilai DER yang tinggi disebabkan oleh tingkat hutang perusahaan yang juga tinggi. Dalam Trade off theory, perusahaan akan menerbitkan hutang sampai pada titik tertentu yaitu titik optimal. Jika perusahaan berhutang terlalu melebihi titik optimal, perusahaan akan menanggung beban bunga yang terlalu tinggi. yang dapat memberikan risiko kebangkrutan yang tinggi pada perusahaan akibat dari tingginya tingkat hutang perusahaan. Hal tersebut dapat menjadi sinyal negatif bagi investor yang berdampak pada turunnya nilai perusahaan. Berdasarkan data yang telah diolah, indeks kompas100 merupakan indeks yang emitennya memiliki tingkat hutang yang cukup tinggi dengan rata-rata sebesar $148 \%$. Hasil dari penelitian ini sesuai dengan penelitian yang dilakukan oleh Sianipar et al, (2018), Novalia et al, (2015), Permana \& Rahyuda, (2018), dan Kahfi et al. (2018).

4. TATO (X4) berpengaruh positif dan signifikan terhadap Nilai Perusahaan (Y) yang diproksikan dengan Tobin's $Q$ dimana pada saat TATO meningkat, akan berpengaruh pada meningkatnya Nilai Perusahaan. Nilai TATO menunjukkan kemampuan perusahaan dalam menghasilkan laba atas penjualan sehingga semakin tinggi TATO mengindikasikan kinerja perusahaan yang semakin baik. Peningkatan nilai TATO dapat memberikan sinyal positif kepada investor untuk berinvestasi pada perusahaan karena investor bergantung pada sinyal fundamental dari perusahaan. Hasil penelitian ini sesuai dengan penelitian yang dilakukan oleh Rinnaya et al. (2016), Sianipar et al. (2018), Kahfi et al. (2018), dan Lumentut \& Mangantar, (2019). 


\section{KESIMPULAN DAN SARAN}

\subsection{Kesimpulan}

Dari hasil penelitian disimpulkan bahwa rasio profitabilitas (ROE), rasio likuiditas (CR), rasio aktivitas (TATO) berpengaruh positif dan signifikan terhadap nilai perusahaan. Tingginya nilai ketiga rasio tersebut semakin baik dampaknya kepada perusahaan. Pada rasio solvabilitas (DER), memiliki pengaruh negatif dan signifikan terhadap nilai perusahaan. Hal tersebut menandakan setiap penurunan nilai DER akan diikuti dengan peningkatan dari nilai perusahaan. Berdasarkan hasil penelitian, faktor-faktor fundamental seperti kinerja keuangan perusahaan dapat dijadikan suatu pertimbangan oleh investor dalam melakukan pembelian saham pada perusahaan indeks kompas100.

\subsection{Saran}

Berdasarkan hasil penelitian, Bagi pihak manajemen dapat memperhatikan variabel rasio profitabilitas, likuiditas, solvabilitas dan aktivitas karena keempat variabel tersebut memiliki pengaruh yang signifikan terhadap nilai perusahaan. Berdasarkan hal tersebut diharapkan manajemen dapat lebih baik dalam mengelola aset, ekuitas, dan hutang perusahaan agar dapat memperoleh return tinggi yang tentunya akan berdampak pada nilai perusahaan. Bagi pihak investor, apabila hendak melakukan investasi dapat memperhatikan kinerja keuangan perusahaan dari tahun ke tahun dengan melihat rasiorasio keuangan perusahaan Bagi penelitian selanjutnya, terdapat nilai $\mathrm{R}^{2}$ sebesar $67,2 \%$ pada penelitian ini yang berarti peneliti selanjutnya dapat mempertimbangkan variabel lain yang mempengaruhi nilai perusahaan karena masih terdapat $32,8 \%$ variabel bebas di luar model regresi. Peneliti selanjutnya juga dapat memperpanjang periode penelitian dan menggunakan industry maupun indeks yang lain sebagai objek penelitian agar memperoleh gambaran maupun hasil yang lebih baik.

\section{DAFTAR PUSTAKA}

Amijaya, T., Rini Demi Pangestuti, I., \& Mawardi, W. (2015). Analisis Pengaruh Struktur Modal, Profitabilitas, Likuiditas, Kebijakan Dividen, Sales Growth, dan Ukuran Perusahaan Terhadap Nilai Perusahaan (Studi pada Perusahaan Manufaktur yang Listed di BEI Periode 2012-2014).

Anzlina, C. W., \& Rustam. (2013). Pengaruh Tingkat Likuiditas, Solvabilitas, Aktivitas, dan Profitabilitas Terhadap Nilai Perusahaan Real Estate dan Property di BEI Tahun 2006-2008. Jurnal Ekonom, 16(2), 67-75.

Bhekti Fitri, P. (2013). Pengaruh Ukuran Perusahaan, Leverage, Price Earning Ratio dan Profitabilitas terhadap Nilai Perusahaan. Jurnal Ilmu Manajemen (JIM), 1(1).

Brigham, E. F., \& Houston, J. F. (1999). Manajemen Keuangan. Erlangga.

Dr.Kasmir, S.E., M. M. (2014). Pengantar Manajemen Keuangan (Kedua). Prenadamedia Group.

Dwi, A. (2017). Pengaruh Aktivitas Rasio Keuangan terhadap Nilai Perusahaan (Studi Pada Industri Manufaktur). Jurnal STIE Semarang, 9, 49.

Fahmi, I. (2016). Pengantar Manajemen Keuangan. Alfabeta.

Ghozali, I. (2016). Aplikasi Analisis Multivariete IBM SPSS. In Semarang, Universitas Diponegoro.

Haryadi, E. (2016). Pengaruh Sizeperusahaan, Keputusan Pendanaan, Profitabilitas dan Keputusan Investasi terhadap Nilai Perusahaan. Jurnal Akuntasi Vol. 3 No. 2 Juli 2016,

$3(2)$,

84-100.

https://e- 
jurnal.lppmunsera.org/index.php/Akuntansi/article/download/211/272/

Haryati, W., \& Ayem, S. (2016). PENGARUH RETURN ON ASSETS, DEBT TO EQUITY RATIO, DAN EARNING PER SHARE TERHADAP NILAI PERUSAHAAN (Studi Kasus Pada Perusahaan Food and Beverages Yang Terdaftar Di BEI Periode 20092011). Jurnal Akuntansi, 2(1), 43-55. https:// doi.org/10.24964/ja.v2i1.23

Hasania, Z., Murni, S., \& Mandagie, Y. (2016). Pengaruh Curret Ratio, Ukuran Perusahaan, Struktur Modal, dan ROE Terhadap Nilai Perusahaan Farmasi yang Terdaftar di Bursa Efek Indonesia Periode 2011-2014. Jurnal Berkala Ilmiah Efisiensi, 16(03).

Jantana, I. (2012). Pengaruh Struktur Modal, Profitabilitas, Dan Likuiditas Terhadap Nilai Perusahaan Pada Perusahaan Sektor Barang Konsumsi Sub-Sektor Rokok Di Bei Tahun 2007-2011. Jurnal Manajemen, Strategi Bisnis, Dan Kewirausahaan, 1, 1-30.

Jensen, M. C., \& Meckling, W. H. (1976). Theory of the firm: Managerial behavior, agency costs and ownership structure. Journal of Financial Economics. https:// doi.org/10.1016/0304-405X(76)90026-X

Johnson. (2015). Analisis Total Assets Turnover dan Return On Equity pada PT. Aksaha Wira Internasional, Tbk. yang terdaftar di Bursa Efek Indonesia. Jurnal Financial, 1(1), 1-6.

Kahfi, M. F., Pratomo, D., \& Aminah, W. (2018). Pengaruh Current Ratio, Debt to Equity Ratio, Total Assets Turn Over dan return On Equity Terhadap Nilai Perusahaan ( Studi Kasus Pada Perusahaan Manufaktur Sektor Food and Beverage Yang Terdaftar Di Bursa Efek Indonesia Pada Tahun 2011 - 2016 ). E-Proceeding of Management, 5(1), 566-574.

Kushartono, R. C., \& Nurhasanah, N. (2018). Analisis Pengaruh Rasio Keuangan Terhadap Nilai Perusahaan Pada Perusahaan Yang Tergabung Dalam Indeks Lq45 Periode 2010 -2016. Buana Ilmu, 2(1), 108-125. https://doi.org/10.36805/bi.v2i1.278

Lubis, I. L., Sinaga, B. M., \& Sasongko, H. (2017). Pengaruh Profitabilitas, Sruktur Modal, Dan Likuiditas Terhadap Nilai Perusahaan. Jurnal Aplikasi Bisnis Dan Manajemen, 3(3), 458-465. https://doi.org/10.17358/jabm.3.3.458

Lumentut, F. G., \& Mangantar, M. (2019). Pengaruh Likuiditas, Profitabilitas, Solvabilitas, Dan Aktivitas Terhadap Nilai Perusahaan Mannufaktur Yang Terdaftar Di Indeks Kompas100 Periode 2012-2016. Jurnal EMBA: Jurnal Riset Ekonomi, Manajemen, Bisnis Dan Akuntansi, 7(3), 2601-2610. https://doi.org/10.35794/emba.v7i3.23643

Lumoly, S., Murni, S., \& Untu, V. N. (2018). PENGARUH LIKUIDITAS, UKURAN PERUSAHAAN DAN PROFITABILITAS TERHADAP NILAI PERUSAHAAN (Studi pada Perusahaan Logam dan Sejenisnya yang Terdaftar di Bursa Efek Indonesia). Jurnal EMBA: Jurnal Riset Ekonomi, Manajemen, Bisnis Dan Akuntansi, 6(3), 1108-1117. https:// doi.org/10.35794/emba.v6i3.20072

Moniaga, F. (2013). Struktur Modal, Profitabilitas Dan Struktur Biaya Terhadap Nilai Perusahaan Industri Keramik, Porcelen Dan Kaca Periode 2007 - 2011. Jurnal EMBA, Vol.1 No 4(4), Hal. 433-442.

Novalia, R., Kardinal, \& Wijaya, T. (2015). Pengaruh Faktor-Faktor Fundamental TerhadapNilai Perusahaan Manufaktur Yang TerdaftarDi Bursa Efek. Jurnal Ekonomi Bisnis, 05(3), 1-18.

Permana, A. A. N. B. A., \& Rahyuda, H. (2018). Pengaruh Profitabilitas, Solvabilitas,Likuiditas, Dan Inflasi Terhadap Nilai Perusahaan. E-Jurnal Manajemen Universitas Udayana, $8(3)$, 1577. https://doi.org/10.24843/ejmunud.2019.v08.i03.p15

Rachmawati, D., \& Pinem, D. B. (2015). Pengaruh Profitabilitas, Leverage dan Ukuran Perusahaan Terhadap Nilai Perusahaan. 18(1). 
Rinnaya, I. Y., Andini, R., \& Oemar, A. (2016). Pengaruh Profitabilitas, Rasio Aktivitas, Keputusan Pendanaan, Keputusan Investasi Terhadap Nilai Perusahaan (Studi Empiris pada Perusahaan Manufaktur yang Terdaftar di BEI Tahun 2010-2014). Journal Of Accounting, 2(2), 1-18.

Salama, M., Rate, P. Van, \& Untu, V. N. (2019). Pengaruh Keputusan Investasi, Keputusan Pendanaan Dan Kebijakan Dividen Terhadap Nilai Perusahaan Pada Industri Perbankan Yang Terdaftar Di Bei Periode 2014-2017. Jurnal EMBA: Jurnal Riset Ekonomi, Manajemen, Bisnis Dan Akuntansi, 7(3), 2651-2660. https://doi.org/10.35794/emba.v7i3.23715

Sianipar, R. T., Tarigan, P., Jubi, J., \& Inrawan, A. (2018). Pengaruh Likuiditas, Solvabilitas, Aktivitas Dan Profitabilitas Terhadap Nilai Perusahaan Pada Pt Astra Internasional, Tbk Yang Terdaftar Di Bursa Efek Indonesia. SULTANIST: Jurnal Manajemen Dan Keuangan, 3(2). https://doi.org/10.37403/sultanist.v3i2.57

Sri, A., Dewi, M., \& Wirajaya, A. (2013). Pengaruh Struktur Modal, Profitabilitas Dan Ukuran Perusahaan Pada Nilai Perusahaan. E-Jurnal Akuntansi, 4(2), 358-372.

Susanti, R. (2010). Analisis Faktor-Faktor yang Berpengaruh terhadap Nilai Perusahaan (Studi Kasus pada Perusahaan Go Public yang listed tahun 2005-2008). Skripsi Sarjana Ekonomi, Program Sarjana Universitas Diponegoro, Semarang.

Triagustina, L., Sukarmanto, E., \& Helliana, H. (2014). Pengaruh Return On Asset (ROA) Dan Return On Equity (ROE) Terhadap Nilai Perusahaan Pada Perusahaan Manufaktur Subsektor Makanan Dan Minuman Yang Terdaftar Di Bursa Efek Indonesia Periode 2010-2012. Prosiding Akuntansi, 28-34.

Van Horne, J. C., \& Wachowicz Jr, J. M. (1995). Prinsip-Prinsip Manajemen Keuangan (Kesembilan). A Simon \& Schuster Company.

Wahyuni, W., A P, I. N. N., \& Hidayati, S. A. (2018). Pengaruh Profitabilitas Terhadap Nilai Perusahaan Dengan Pengungkapan Corporate Social Responsibility (Csr) Sebagai Variabel Pemoderasi (Studi Empiris Pada Perusahaan Pertambangan Yang Terdaftar Di Jakarta Islamic Index Periode 2010 - 2017). Jmm Unram - Master of Management Journal, 7(2), 72. https:// doi.org/10.29303/jmm.v7i2.383

Wijaya, B., \& Sedana, I. (2015). Pengaruh Profitabilitas Terhadap Nilai Perusahaan (Kebijakan Dividen Dan Kesempatan Investasi Sebagai Variabel Mediasi). E-Jurnal Manajemen Universitas Udayana, 4(12), 253308.

Wiratna Sujarweni, V. (2019). Analisis Laporan Keuangan. Teori, Aplikasi, \& Hasil Penelitian. Pustaka Baru Press. 